\title{
MOTIVASI SULUK 5 HARI DAN KETEKUNAN BERIBADAH PENGAMAL TAREKAT NAQSYABANDIYAH SYEKH H. MHD.IHSAN HARAHAP (Studi Analisis pada Murid Usia Minus 40 Tahun)
}

\author{
ARMYN HASIBUAN \\ Lecturer of Da'wa and communication sciences Faculty at IAIN Padangsidimpuan. \\ Email: armyn.iain@gmail.com
}

\begin{abstract}
This research is a study of analysis on a pupil's age minus 40 years. The formulation of the problem is what motivation suluk 5 days on the Shaykh Naqshbandi guidance $h$. Mhd. Ihsan Harahap and how perseverance serve pupils aged 40 years after it was completed minus suluk 5 days.This research is descriptive qualitative research. The time this research was planned for 6 months where the subject is referred to in this research was Sheikh h. Mhd. Ihsan Harahap and his disciple. The method used in determining the subject of the research using the method of pourposive sampling. The results of the study found the description about the motivation of suluk 5 days on the Shaykh Naqshbandi guidance $\mathrm{H}$. Mhd. Ihsan Harahap viewable from two things; first the willingness of his congregation and the second from the whims of Sheikh h. Mhd. Ihsan Harahap and Caliphs as the loyal right hand man helped him. Motivation in the presence the call of soul worship in the disciples. Then extrinsic existence of socialization through Da'wah of Shaykh, the influence of friends, the mindset of people that worship time efficiency in suluk.
\end{abstract}

Key Words: Motivation, Mysticism, Worship and Tarekat Participants

\begin{abstract}
Abstrak
Penelitian ini merupakan penelitian analisis pada usia pengamal minus 40 tahun. Rumusan masalah adalah apa motivasi Suluk 5 hari pada Naqshbandi Syaikh bimbingan $\mathrm{H}$. Mhd. Ihsan Harahap dan bagaimana ketekunan beribadah murid usia 40 tahun setelah itu selesai suluk 5 hari. Penelitian ini merupakan penelitian deskriptif kualitatif. Waktu penelitian ini direncanakan selama 6 bulan di mana subjek dimaksud dalam penelitian ini adalah Sheikh $\mathrm{h}$. Mhd. Ihsan Harahap dan muridnya. Metode yang digunakan dalam menentukan subjek penelitian dengan menggunakan metode pourposive sampling.Hasil penelitian ini menemukan tentang motivasi suluk 5 hari pada Naqshbandi Syaikh bimbingan $H$. Mhd. Ihsan Harahap dapat dilihat dari dua hal; pertama kesediaan jamaahnya dan yang kedua dari keinginan dari Sheikh $h$. Mhd. Ihsan Harahap dan khalifah sebagai tangan kanan yang setia menolongnya. Dengan adanya motivasi untuk seruan ibadah jiwa (suluk) pada para murid. Kemudian keberadaan sosialisasi ekstrinsik melalui Dakwah Syaikh, pengaruh teman, pola pikir orang yang menyembah efisiensi waktu dalam melaksanakan suluk.
\end{abstract}

Kata Kunci: Motivasi, Suluk, Beribadah dan Pengamal Tarekat 


\section{PENDAHULUAN}

Suluk adalah atribut dari tarekat, sedangkan tarekat adalah perpanjangan tangan dari tasawuf. Ungkapan ini mengindikasikan bahwa suluk merupakan satu metode aplikasi dari konsep tasawuf. Berbagai konsep tasawuf diungkapkan para ahli dan peneliti menjadi mediator dalam mengembangkan metode dan memperdalam ketauhidan, dimana tarekat itu diaplikasikan lagi dalam bentuk suluk, sekaligus membuat kuantitas ibadah bertambah. Seorang sufi yang kemudian disebut dengan 'syekh' mengembangkan dan memberdayakan muridnya dengan cara suluk. ${ }^{1}$

Suluk yang ada pada tarekat, bertujuan untuk membina murid menjadi manusia yang taat beribadah, memiliki spiritual dan mental yang sehat. Posisi suluk dalam ketarekatan menjadi sarana bagi para murid untuk mencapai tujuan dari tasawuf, yaitu mencapai tingkat dan derajat yang tinggi di sisi Allah.Yakni, muqarrabin (orang yang dekat dengan Allah), melalui jalan beribadah kepada-Nya. ${ }^{2}$ Aktivitas suluk sarat dengan berbagai amalan zikir dengan berbagai pola yang bervariasi. Ada pola istighfar (meminta ampun), tasbih (memuji), tahlil (membesarkan), tahmid (memuja), doa (meminta) dan sebagainya. Aktivitas zikir lebih banyak mempengaruhi aspek-aspek spiritual, dimana para murid dapat berintegrasi dan berinteraksi dengan berbagai pola dalam berzikir sesuai dengan bimbingan dari syekh. ${ }^{3}$

Ketekunan beribadah ini amat berkaitan dengan aspek rohaniah dan aspek jasmaniah. Aspek rohaniah adalah adanya semangat yang membesarkan kemauan beribadah. Pada aspek jasmaniah, erat kaitannya pengembangan aspek spiritual. Seperti halnya ungkapan Arifin dan Said: "pada masa lalu umat manusia lebih tertumpu pada pembangunan material. Akibatnya kebanyakan umat di antara kita menjadi manusia yang materialitis". ${ }^{4}$ Stetmen ini menunjukkan aspek jasmaniah adalah berpotensi kepada keburukan, namun melalui suluk potensi ini dibina dan dipadukan dengan potensi rohaniah menjadi faktor yang sangat mendukung satu dengan yang lain, namun kunci utamanya adalah semangat beribadah sehingga mampu bertahan.

Berkaitan dengan hal itu, ketekunan beribadah tentu, dapat dilihat dari berbagai faktor antara lain termasuk usia. Usia dewasa antara 20-30 merupakan usia yang potensial dalam bekerja. Jika orang (usia plus 40 tahun) tekun melaksanakan ibadah melalui suluk, adalah hal yang wajar karena pemikirannya sudah condong dengan ukhrawi, sebab usia sudah dekat dengan ajal, sehingga ketekunan ibadahnya pun tidak diherankan lagi lebih banyak. Syekh H. Mhd. Ihsan Harahap adalah salah satu mursyid di bidang persulukan

${ }^{1}$ Najamuddin Amin Al-Kurdi, Tanwir Al-Qulub, (Beirut: Dar Al-Fikr, tt), hlm. 578.

${ }^{2}$ Muhammad Fuad Abdul Baqi, Al-Mu'jam Al-Mufarros li Al-Fazhi Al-Qur'an Al-Karim, (Beirut: Dar Fikr, tth), hlm. 560-562.

${ }^{3}$ Fuad Said, Hakekat Tarekat Naqsyabandiyah, (Jakarta: Pustaka Al-Husna, 1994), hlm. 47.

${ }^{4}$ Bey Arifin dan Abdullah Said, Rahasia Ketahanan Mental dan Bina Mental dalam Islam, (Surabaya: Al-Ikhlas, 1981), hlm. 123-124. 
yang dikenal di wilayah di kota Padangsidimpuan (Padangsidimpuan Angkola Julu) dan Tapanuli Selatan (Kecamatan Angkola Barat). Beliau sendiri berdomisili di Desa Mompang Julu Pokenjior Kecamtan Padangsidmpuan Angkola Julu. Popularitasnya di Tapanuli Selatan dan kota Padangsidimpuan menjadikan dia menjadi syekh yang sering mensulukkan dan menjadi pembimbing dalam aktivitas suluk. ${ }^{5}$

Beliau memiliki murid yang beraneka ragam, ada murid telah lanjut usian (lansia) dan ada yang minus 40 tahun dengan latar belakang, status dan pekerjaan yang berbedabeda. Tetapi setelah diamati dengan seksama, mereka yang berusia minus 40 tahun pada umumnya memiliki ketekunan beribadah. Perbedaan corak usia kedua murid di atas, tentu secara teori akan berbeda pula kecendrungan, keinginan dan ketekunan beribadahnya. Demikian juga halnya motivasi dan kegiatan suluk bagi usia minus 40 tahun akan ada kesenjangan atau ketidakcocokan dengan orangtua yang lansia apalagi gabung dalam satu persulukan di bawah bimbingan seorang mursyid, dalam hal ini Syekh H. Mhd. Ihsan Harahap.

\section{KONSEP MOTIVASI}

Setiap individu atau seseorang melakukan sesuatu didasarkan kepada daya pendorong yang ada dalam dirinya sendiri. Seseorang melakukan suatu perilaku tertentu yang berbeda dengan orang lain adalah adanya faktor pendorong yang disebut dengan motivasi. Menurut Kamus Bahasa Indonesia motivasi memiliki tiga pemaknaan dengan sudut pandang yang berbeda yaitu

1. Dorongan yang timbul pada diri seseorang secara sadar atau tidak untuk melakukan suatu tindakan dengan tujuan tertentu.

2. Usaha yang dapat menyebabkan seseorang atau kelompok orang tertentu tergerak melakukan sesuatu karena ingin mencapai tujuan yang dikehendakinya atau mendapat kepuasan dengan perbuatannya.

3. Perilaku berupa dorongan lekat diri yang ditujukan untuk sesuatu tujuan atau keperluan. ${ }^{6}$

Morgan dalam Soekamto mendefinisikan motivasi sebagai tenaga pendorong atau penarik yang menyebabkan adanya tingkah laku ke arah stau tujuan tertentu. ${ }^{7}$ Mc. Donald sebagaimana dikutip oleh Hamalik mengatakan bahwa motivasi adalah suatu perubahan energi dalam diri (pribadi) seseorang yang ditandai dengan timbulnya perasaan dan reaksi untuk mencapai tujuan dari rumusan tersebut ada tiga unsur yang saling berkaitan, yakni:

\footnotetext{
${ }^{5}$ Studi Pendahuluan, Wawancara dengan Syekh H. Mhd. Ihsan Harahap, Mompang, 25 Mei 2014.

${ }^{6}$ Tim Penyusun Pusat Bahasa, Kamus Bahasa Indonesia, (Jakarta: Balai Pustaka, 2008), hlm. 973.

${ }^{7}$ Toeti Soekamto, dkk, Prinsip Belajar dan Pembelajaran, (Jakarta: PPAI Dirjen Dikti-Depdikbud, 1993), hlm.
} 41. 
1. Motivasi dimulai dari adanya perubahan energi dalam pribadi. Perubahan tersebut terjadi disebabkan oleh perubahan tertentu pada sistem neurofisiologis dalam oragnisme manusia, misalnya: karena terjadi perubahan pada sistem percernaan maka timbul motif lapar. Namun demikian, ada juga perubahan energi yang tidak diketahui.

2. Motivasi ditandai oleh timbulnya perasaan. Mula-mula berupa ketegangan psikologis, lalu berupa suasana emosi. Suasana emosi ini menimbulkan tingkah laku yang bermotif. Perubahan ini dapat diamati pada perbuatannya. Contoh, seseorang terlibat dalam diskusi, dia tertarik pada masalah yang sedang dibicarakan, karenanya dia bersuara/ mengemukakan pendapatnya dengan kata-kata yang mancar dan tepat.

3. Morivasi ditandai oleh rekasi-reaksi untuk mencapai tujuan. Pribadi yang bermotivasi memberikan respons-respons ke arah suatu tujuan tertentu. Respons-respons itu berfungsi mengurangi ketegangan yang disebabkan oleh perubahan eneri dalam dirinya. Tiga respons merupakan satu langkah ke arah mencapai tujuan. Contoh, si Polan ingin mendapat hadiah, maka ia belajar misalnya mengikuti ceramah, bertanya, membaca buku, menempuh tes dan sebagainya. ${ }^{8}$

Berdasarkan penjelasan di atas, maka dapat dipahami bahwa dalam motivasi terkandung adanya keinginan yang mengaktifkan, menggerakkan, menyalurkan dan mengarahkan sikap dan perilaku individu. Oleh karena itu, ada tiga komponen utama dalam motivasi, yaitu kebutuhan, dorongan dan tujuan. ${ }^{9}$ Motivasi jika dilihat dari sudut pandangnya, maka motivasi terbagi dua yaitu motivasi instrinsik dan motivasi ekstrinsik. ${ }^{10}$

1. Motivasi instrinsik adalah dorongan yang berasal dari dalam diri seseorang bukan karena oleh faktor luar. Misalnya ia gemar membaca bukan atas dorongan orang lain tetapi keinginan sendiri.

2. Motivasi ekstrinsik adalah dorongan untuk melakukan sesuatu atas faktor luar dari dirinya, termasuk karena kondisi yang diciptakan oleh lingkungan itu sendiri. Misalnya seorang murid termotivsi untuk beribadah karena takut dengan mursyidnya dan lingkungan yang memaksanya untuk taat dan patuh beribadah. Jadi seseorang melakukan sesuatu aktivitas didasarkan kepada kedua motivasi tersebut.

Motivasi mempunyai tujuan untuk menggerakkan atau menggugah seseorang agar timbul keinginan dan kemauannmya untuk melakukan sesuatu sehingga dapat memperoleh hasil atau mencapai tujuan tertentu. Mengadopsi dari teori psikologi pendidikan yang dikemukakan oleh Ahmad Rohani dan Abu Ahmadi mengemukakan fungsi motivasi bagi siswa misalnya adalah memberi semangat dan mengaktifkan siswa supaya tetap berminat dan siaga. Memusatkan perhatian siswa pada tugas-tugas tertentu yang berhubungan

${ }^{8}$ Oemar Hamalik, Kurikulum dan Pembelajaran, (Jakarta: Bumi Aksara, 1995), hlm. 106. ${ }^{9}$ Dimyati dan Mujiono, Belajar dan Pembelajaran, (Jakarta: Rineka Cipta, 1999), hlm. 80. ${ }^{10} \mathrm{Ibid}, \mathrm{hlm} .72$ 
dengan pencapaian tujuan belajar, dan membantu memenuhi kebutuhan akan hasil jangka pendek dan hasil jangka panjang. ${ }^{11}$

Unsur-unsur di atas tentunya dengan pendekatan pendidikan, relevansinya dalam ketarekatan tentunya unsur di atas juga sama dengan pengamal tarekat sebagai murid dari mursyid dalam bersuluk. Dimana setiap murid dalam bersuluk juga memilkinya meskipun tidak berurutan dan bias saja seorang salik tentu melihat kondisi dirinya dari berbagai unsur. Biasanya haus akal ilmu dan keridhaan Tuhan membuatnya bercita-cita melakukan aktivitas peramalan yakni suluk. Apalagi kemampuan belajar ekonomi dam dan riyadhah, kesungguhan latihan beramal ibadah masih kuat, membuatnya optimistis,dinamis, opimis, dinamis mengkondisikan diri, lingkugan dan menari guru sekaligus mursyid yang berbeda konteksnya.

Berdasarkan pembahasan tentang unsur-unsur pokok motivasi maka dapat dijabarkan faktor-faktor dari motivasi dalam diri sendiri yakni:

1. Faktor kebutuhan yakni adanya keinginan dalam diri seseorang untuk bersungguhsungguh memenuhi hasrat secara lahiriyah maupun bathiniyah.

2. Faktor lingkungan; ada kesungguhan dalam diri seseorang disebabkan oleh keadaan sekitar yang mendesaknya secara psikologis.

3. Faktor sosial; adanya kesungguhan pada diri seseorang karena kompleksitas dirinya sehingga menempatkannya pada tatanan sosial yang baik dan menjadi kekuatan pada dirinya untuk memegang amanah atau jabatan di mata masyarakat.

Ketiga faktor ini secara umum tentunya dapat dipersempit menurut pembahasan dan ranah kajian untuk mengetahui tujuan dari motivasi ini sendiri. Seperti halnya pada pembahasan ilmu tasawuf tarekat tentunya ketiga faktor ini memiliki peranan yang cukup signifikan sehingga para sufi atau salikin memiliki motivasi yang kuat dalam bertasawuf. Kekuatan motivasi inilah yang menjadikan para sufi membentuk sebuah jalan (tarigah) dalam mencapai tujuan dari tasawuf yakni mardhatillah.

\section{SULUK}

Suluk secara bahasa berasal dari bahasa Arab yakni salaka, yasluku, salik. ${ }^{12}$ Kata salik diadopsi dalam bahasa Indoensia menjadi suluk, artinya jalan menuju kesempurnaan batin dalam ajaran tasawuf. ${ }^{13}$ Salah satu kegiatan pokok ajaran tarekat ialah berzikir dalam upaya untuk memperkuat keteguhan hati menuju kedekatan diri kepada Allah untuk melakukan zikir yang lebih intensif, dapat dilakukan melalui suluk. Tujuannya ialah untuk latihan pengenalan dan pengejawantahan sekaligus aktivitas spritual. Di antara ulama memberikan pengertian suluk sebagai berikut:

\footnotetext{
${ }^{11}$ Ahmad Rohani dan H. Abu Ahmadi, Pengelolaan Pengajaran, (Jakarta: Rineka Cipta, 2000) hlm. 11.

12 Mahmud Yunus, Kamus Arab-Indonesia, (Jakarta: Hidakarya Agung, 1989), hlm. 177.

${ }^{13}$ Tim Penyusun Pusan Bahasa,......, 2008, hlm. 397.
} 
1. Al- Ardibillah Syekh Muhammod lbrahim: pada hakekatnya suluk mangandung arti mengosongkan diri dari sifat-sifat buruk (maksiat batin) dan mengisinya dengan berbagai sifat terpuji (ketaatan lahir maupun ketaatan batin) dengan tekun dan dengan semangat Tuhannya. ${ }^{14}$

2. Mustafa Zahri: suluk sebenarnya salah suatu perjalanan ruhani para salikin (pengikut suluk) untuk mendekatkan diri kepada Tuhan bukan sekedar untuk mendapatkan nikmat dunia dan akhirat, bukan pula untuk mendapatkan sorotan nur yang menyebabkan mampu mengetahui suratan-suratan nasib, melainkan untuk bisa sedekat mungkin dengan Tuhan. ${ }^{15}$

3. Najamuddin Amin AI-Kurdi: Khlawat (suluk) adalah hadirnya hati para salik mengingat Allah (al-haq) secara totalitas, baik dalam keadaan menyendiri maupun dalam keadaan keramaian manusia. Ada dua macam bentuk suluk, pertama menempati rumah suluk, terasing dari manusia kedua; suluk secara batin saja yaitu batin dalam keadaan hadir dan menyaksikan rahasia al- Haq, sedangkan badaniyah (badannya) tetap bergaul dengan manusia atau masyarakat. ${ }^{16}$

4. Syekh Ahmad al-Alawi: khalwat (suluk) adalah sebuah larangan kecil, Disini saya menempatkan orang baru (salik) untuk menetap selama empat puluh hari untuk menyebut nama Allah setelah berjanji tidak akan meninggalkan tempat itu siang dan malam. ${ }^{17}$

Hal tersebut menggambarkan bahwa yang dimaksud adalah semacam kegiatan sungguh-sungguh menjalani latihan ruhani dengan memperbanyak zikir, lebih khusus dilakukan pada tempat tertentu atas bimbingan syekh tarekat. Di Indonesia sangat dikenal rumah suluk yang difungsikan sebagai tempat berzikir dalam upaya mendekatkan diri kepada Allah. Hati salik senantiasa terpaut dengan Tuhan meskipun berada dalam keramaian, perbaktian mereka tetap saja tertuju kepada Tuhan, perilaku mereka senantiasa terkontrol dalam suasana baik dan terpuji. Kekekalan sifat terpuji sebenarnya inti dari suluk itu sendiri.

Pengikut tarekat menjadikan landasan mereka tentang suluk dari beberapa ayat dan hadis baik secara implisi maupun secara eksplisit.

1. Surah Al-Kahfi ayat 110

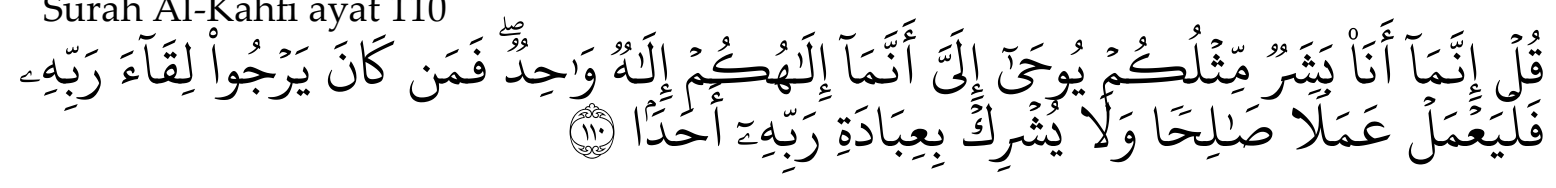

\footnotetext{
${ }^{14}$ Imran Abu Ammar, Di Sekitar Tarekat Naqsyabandiyah, (Kudus: Menara, 1950), hlm. 50.

${ }^{15} \mathrm{Ibid}, \mathrm{hlm} .52$.

${ }^{16} \mathrm{Ibid}, \mathrm{hlm} .53$.

${ }_{17}$ Syekh Ahmad al-Alawi, Wali Sufi Abad 20, terj, Abd Hadi (Bandung: Mizan, 1989), hlm. 7-9.
} 
Artinya: Katakanlah: Sesungguhnya aku ini manusia biasa seperti kamu, yang diwahyukan kepadaku: "Bahwa sesungguhnya Tuhan kamu itu adalah Tuhan yang Esa". Barang siapa mengharap perjumpaan dengan Tuhannya, maka hendaklah ia mengerjakan amal yang saleh dan janganlah ia mempersekutukan seorangpun dalam beribadat kepada Tuhannya"18

2. Hadis Riwayat Bukhari yang menyebutkan bahwa: "Nabi Muhammad saw bersabda: Nabi Muhammad menjalankan khalwat di Gua Hira dengan tujuan beribadat kepada Allah pada beberapa malam yang tidak sebentar". ${ }^{19}$

3. Hadis Riwayat Bukhari dan Muslim yang artinya "Nabi bersabda: Ada tujuh macam orang yang mendapat naungan rahmat dari Allah.. " ketujuh, ialah orang yang berzikir kepada Allah di tempat yang sunyi (berkhalawat) kemudian kedua matanya mencucurkan air mata. ${ }^{20}$

Bagi para salik yang benar-benar menjalankan suluk dengan sungguh, sudah barang tentu hatinya akan terisi dengan berbagai pengetahuan tentang rahasia kebesaran Allah. Abdul Shamad berkata: bahwa dalam keadaan demikian salik akan mendengar seruan Tuhannya dan melihat dengan mata hatinya keelokan hadirat Tuhannya. ${ }^{21}$

\section{METODE PENELITIAN}

Adapun lokasi penelitian ini berada di Kecamatan Angkola Barat dan Padangsidimpuan Angkola Julu. Desa-desa di kedua kecamatan ini merupakan basis Syekh H. Mhd. Ihsan Harahap melaksanakan suluk sehingga penentuan lokasi tergantung dimana beliau melaksanakan suluk namun tidak lepas dari wilayah kedua kecamatan tersebut. Jenis penelitian adalah penelitian kualitatif lapangan. Penelitian kualitatif menurut Denzin dan Lincoln menyatakan bahwa penelitian kualitatif adalah penelitian dengan menggunakan latar alamiah dengan maksud menafsirkan fenomena yang terjadi dan dilakukan dengan jalan melibatkan pendekatan serta metode penelitian. ${ }^{22}$

Moleong mensintesiskan bahwa penelitian kualitatif adalah penelitian yang bermaksud untuk memahami fenomena tentang apa yang dialami oleh subjek penelitian, misalnya perilaku, persepsi, motivasi, tindakan dan lain-lain. Secara holistik dan dengan cara deskripsi dalam bentuk kata-kata dan bahasa, pada suatu konteks khusus yang alamiah dan dengan memanfaatkan metode alamiah. ${ }^{23}$ Pemilihan subjek ini didasarkan pendapat

\footnotetext{
${ }^{18}$ Departemen Agama RI, Al-Qur'an dan Terjemahnya, (Semarang: Toha Putra, 2009), hlm. 56.

${ }^{19}$ Imam Bukhari. Terjemahan Shahih Bukhari, Juz IV, (Semarang: Dahlaq tt.), hlm. 7-9.

${ }^{20}$ Ibid, hlm. 9.

${ }^{21}$ Abdul Shamad Al-Palimbani. Syaral-Salikin Juz I, (Beirut: Maktabah Al-Mukarramah, tt), hlm. 47.

${ }^{22}$ Norman K. Denzin dan Yvonna S. Lincoln (ed), Handbook of Qualitative Research, Terj. Dariyatno dkk., (Yogyakarta: Pustaka Pelajar, 2009), hlm. 2.

${ }^{23}$ Lexy J. Moleong, Metode Penelitian Kualitatif Edisi Revisi, (Jakarta: Rosda Karya, 2010), hlm. 6.
} 
Lofland sebagaimana dikutip Moleong; "pada sumber dan jenis data yang berupa kata-kata dan tindakan". ${ }^{24}$ Maka untuk mendapat jawaban permasalahan dalam penelitian kata-kata dan tindakan dari subjek tersebutlah menjadi sumber data penelitian. Tehnik yang digunakan dalam menentukan subjek penelitian ini menggunakan metode pouposive sampling yakni sampel bertujuan. Dimana peneliti akan terus menggali informasi dari subjek yang satu ke subjek yang lain hingga tercapai tujuan dari penelitian. ${ }^{25}$

\section{HASIL PENELITIAN}

1. Motivasi Suluk 5 Hari Pada Tarekat Naqsyabandiyah Bimbingan Syekh H. Mhd. Ihsan Harahap

Adapun hasil temuan yang dapat dideskripsikan dalam hasil peneltiian di tentang motivasi suluk 5 hari dijabarkan sebagai berikut:

a. Panggilan Jiwa Beribadah

Berdasarkan hasil wawancara dengan Mardan Siagian bahwa adanya panggilan jiwa yang dimaksudkan adalah keinginan murni dari seseorang yang ingin mengikuti persulukan dengan Syekh H. Mhd. Ihsan Harahap. Sebagai sosok syekh yang mumpuni di bidang ketasawufan mampu mempengaruhi dirinya sehingga ikut dalam persulukan. Secara naluriah manusia ingin mendapatkan kebahagiaan dan ketenangan batin, jadi melalui jalan tarekat adalah hal yang tepat agar tidak terjadi penyimpangan pemikiran, perasaan, dan akhlak.

\section{b. Sosialisasi Syekh melalui Dakwah Keliling}

Motivasi ekstrinsik ini adalah merupakan motivasi yang berasal dari luar diri sendiri sehingga terpanggil untuk sesuatu yang hendak dilakukan. Sosialisasi yang dimaksudkan dalam hal ini adalah bentuk dakwah keliling yang dilakukan syekh $\mathrm{H}$. Mhd. Ihsan Harahap kepada masyarakat. Dakwah yang dilaksanakan Syekh H. Mhd. Ihsan Harahap dengan mengisi pengajian umum bagi perkumpulan wirid Yasin di desa-desa yang mengundangnya. Undangan ceramah agama pada kegiatan keagamaan sering membuka dan menjelaskan kajian-kajian tasawuf. Inilah menurut peneliti menjadi faktor motivasi ekstrinsik bagi siapa saja yang ingin menjadi muridnya dalam persulukan. Berkaitan dengan motivasi suluk 5 hari, bahwa murid beliau kebanyakan yang mengikuti suluk adalah karena sosialisasi dan pengenalan diri beliau sebagai mursyid persulukan. Selain itu beliau juga memberikan ajakan dan manfaat suluk bagi kehidupan sehari-hari secara gamblang dan tidak seperti apa yang diwacanakan dalam masyarakat yakni suluk hanya bagi kalangan yang sudah berumur tua.

\section{c. Pengaruh Teman}

${ }^{24}$ Ibid, hlm. 157.

${ }^{25}$ Sugiono. Metode Penelitian Kuantitatif, Kualitatif dan R \& D, (Bandung: Alpabeta, 2008), hlm. 400. 
Adanya pengaruh teman sejawat dalam mengikuti persulukan adalah merupakan faktor ekstrinsik di luar dari diri seseorang. Pendekatan kepada teman tentunya ini banyak dikalangan para kaum ibu yang mencintai keagamaan. Seperti halnya melalui pengajian diumumkan dilaksanakannya persulukan jadi para kaum ibu ikut serta mendaftar. Sebagian besar kaum ibu yang sudah memiliki kemampuan untuk bersuluk lebih banyak bercerita tentang persulukan sehingga memotivasi orang lain agar ikut serta dalam persulukan. Ada pula sebagian janda-janda tua yang kurang cocok dengan anak-anak dan menantunya sehingga ia menerima saran dari teman-temannya untuk ikut dalam kegiatan suluk bahkan tinggal di perpondokan yang ada pondoknya seperti di Sikarang-karang, Basilam dan daerah Padang Bolak.

\section{d. Efisiensi Waktu Beribadah}

Berkaitan dengan pelaksanaan persulukan selama 5 hari, Syekh H. Mhd. Ihsan Harahap memang tidak terlalu sering melaksanakannya karena muridnya lebih banyak mengikuti pelaksanaan suluk yang biasa. Pelaksanaan suluk 5 hari menurut syekh H. Mhd. Ihsan Harahap adalah

1) Permintaan dari kurangnya dilaksanakan suluk 10 hari sehingga pada waktu yang lain dilaksanakan penambahan waktu selama 5 hari.

2) Sebagai bentuk suluk yang sederhana dan lebih mudah dibandingkan dengan suluk selama 20 hari 40 hari.

3) Memang ada sebagian murid yang masih taraf pemula dan memiliki kesibukan dengan berbagai masalah ekonomi, urusan keluarga, dan membagi waktu. Menurutnya pelaksanaan suluk 5 hari menjadi lebih efektif untuk dapat ikut serta dalam persulukan.

4) Terkadang suluk 5 hari adakalanya sebagai bentuk pembukaan bagi muridnya yang masih pemula dan bentuk dakwah yang sederhana. Inilah yang menurut beliau sebagai solusi suluk bagi orang yang benar-benar banyak kesibukan duniawinya.

Berdasarkan hasil rangkuman pernyataan di atas bahwa pelaksanaan suluk 5 hari bagi Syekh H. Mhd. Ihsan Harahap adalah bentuk solusi dan dakwah bagi yang ingin mendekatkan diri secara khusus kepada Allah Swt. Memeng beliau menjelaskan juga bahwa pelaksanaan suluk 5 hari banyak yang menganggapnya adalah bentuk suluk yang tidak pernah dilaksanakan para Syekh atau mursyid yang lain.

2. Ketekunan Beribadah Murid Usia Minus 40 Tahun Setelah Selesai Suluk 5 Hari Tarekat Naqsyabandiyah Bimbingan Syekh H. Mhd. Ihsan Harahap

Ketekunan beribadah adalah suatu hal yang diniscayakan Allah Swt kepada hamba-hambanya. Ketekunan beribadah yang dimaksudkan dalam penelitian ini adalah dimana murid suluk bimbingan Syekh H. Mhd. Ihsan Harahap setelah selesai 
melaksanakan persulukan selama 5 hari. Adab-adab yang diterapkan selama melaksanakan suluk, terdapat juga adab yang harus dilaksanakan murid suluk setelah selesai suluk dan kembali ke lingkungan masyarakat..

\section{a. Keaktifan dalam Beribadah}

Dikatakan aktif dalam beribadah yang dimaksudkan dalam hal ini adalah pelaksanaan ibadah yang tetap dan tidak tertinggal. Sebagaimana ibadah dalam hal ini adalah ibadah yang mahdah, maksudnya ibadah wajib dan ibadah yang sunnah yang dilaksanakan secara berjamaah dan secara individu.

1). Menjaga waktu shalat

Berkaitan dengan shalat yang sifatnya sunat maka beliau menekankan adanya agar tetap dilaksanakan. Hal ini sejalan dengan keterangan Salman Paris Hutapea mengatakan bahwa shalat sunat dalam bentuk apa saja, baik shalat ba'diyah, qabliyah, shalat Dhuha dan shalat lainnya, apalagi shalat tahajjud sangat penting untuk dilaksanakan karena shalat sunat tersebut adalah nilai tambahan dari ibadah yang wajib. Ia sendiri juga berusaha setiap hari shalat-shalat ini dan berusaha mengejar jadwal waktu shalat ke mesjid. ${ }^{26}$

\section{2). Peramalan Ibadah Nawafil}

Peramalan yang dimaksudkan dalam penelitian ini adalah berkaitan dengan pelaksanaan ibadah yang bersifat sunat. Ibadah sunat dalam tasawuf tarekat diposisikan sebagai bentuk pendekatan diri kepada Khalik secara khusus. Sebab ibadah wajib dianggap hanya membayar utang dan janji dengan Allah Swt. Penekanan dan doktrinasi Syekh H. Mhd. Ihsan Harahap tentunya wajib dilaksanakan sebagai muridnya.

3). Wirid dan Zikir

Wirid dan zikir adalah sebagai bentuk pengamalan yang temasuk dalam kateogori ketekunan beribadah. Dalam hal ini peneliti melihat bahwa wirid dimaknai oleh Syekh H. Mhd. Ihsan Harahap adalah suatu bentuk peribadatan yang dilaksanakan secara kontinu dan terus menerus dimana murid dimotivasi untuk mempunyai wirid sebagai amalan kontiniu memiliki hikmah dan rahasia yang tidak diketahui. Sedangkan zikir itu adalah ibadah yang amat luas tanpa dibatasi dan ada dilaksanakan berupa bacaan-bacaan khusus yang dilaksanakan pada waktu tertentu seperti habis shalat atau di waktu senggang. Hal ini sejalan dengan pernyataan Syekh H. Mhd. Ihsan Harahap bahwa zikir tersebut adalah untuk menghaluskan hati melihat hal-hal yang bersifat hikmah dari setiap pekerjaan sehari-hari kita. Zikir jika menjadi wirid yang tetap menjadikan 
pribadi seseorang dapat membuka hijab dan terbuka kasyaf menuju takwa kepada Allah Swt.

\section{b. Keaktifan dalam Keberagamaan}

Syekh H. Mhd. Ihsan Harahap menegaskan bahwa ibadah yang dilaksanakan secara individu kepada Allah Swt adalah ibadah yang mendekatkan diri kepada-Nya secara hablum min Allah namun selain itu hubungan kepada mahluk hablum min nas lainnya terutama manusia adalah penting untuk dijaga dan diperbaiki. Hal-hal inilah yang menjadi dasar analisa peneliti bahwa ibadah ghaira mahdah bagi murid suluk bimbingan Syekh H. Mhd. Ihsan Harahap setelah selesai suluk di dalam masyarakat sehingga dapat bersosialisasi, memposisikan mereka orang terhormat, karena mereka bersilaturrahmi dan bergaul dengan baik dengan siapa saja.

Beberapa bentuk ibadah mahdah tersebut yang menjadi hasil analisa peneliti sebagai bentuk ketekunan beribadah adalah sebagai berikut:

1). Menjenguk Orang Sakit dan Meninggal

Menjeguk orang sakit tentunya adalah perkara yang dianjurkan oleh Rasullulah Saw. Beliau juga mengaskan bahwa nilai yang terkandung dalam menjenguk saudara atau orang lain yang ditimpa sakit atau meninggal adalah bentuk silaturrahmi yang dapat meningkatkan hubungan dengan orang lain, tentunya niat ikhlas karena Allah Swt akan mendapat rahmat dan pahala. Ibadah semacam inilah yang kemudian peneliti menilai bahwa menjenguk orang sakit dan meninggal adalah ibadah yang mendapat dua ganjaran, salah satu diperoleh secara cepat di dunia ini kedua di akhirat ada pahala dua gunung Uhud. Hal ini memang sudah menjadi salah satu ajaran islam dan harus diaplikasikan dalam akhlak tasawuf. ${ }^{27}$

\section{2). Aktif mengikuti Ceramah Agama}

Ceramah agama merupakan bentuk ibadah yang ghaira mahdah, namun bagi murid Syekh H. Mhd. Ihsan Harahap seolah-olah obat merupakan ibadah yang sunat muakkad. Mendengarkan ceramah agama tentunya adalah suatu pengembangan ilmu pengetahuan. Tidak hanya pada saat-saat tertentu seperti Maulid, Isra'miraj, dan penyambutan bulan suci Ramadhan pada acara-acara televisi juga harus ditonton dibandingkan dengan menonton sinetron yang banyak mengajarkan dengki dan iri hati.

3). Menjalin Silaturahmi

Satu hal yang menonjol dari murid Syekh H. Mhd. Ihsan Harahap adalah silaturrahmi yang erat antara sesama murid ataupun dengan guru, bahkan 
dengan orang lain. Tatanan menjalin silaturrahmi antara sesama murid cukup baik hal ini didasarkan pada pelaksanaan suluk yang secara bergilir pada setiap desa. Kekompakan antara murid suluk tetap terjalin dengan komunikasi yang baik.

4). Menghindari hal-hal yang Syubhat

Upaya mendekatkan diri kepada Allah Swt, hukum merupakan landasan formal yang wajib ditaati. Kejelasan hukum tentunya menjadi patokan dalam berbuat sehingga Syekh $\mathrm{H}$. Mhd. Ihsan Harahap menekankan bagi para muridnya khususnya pemula agar menghindari hal-hal yang belum jelas hukum kehalalannya. Lebih lanjut beliau juga mengatakan beberapa hal yang sering ditekankan pada suluk 5 hari adalah jangan memakan makanan jika tidak diketahui seluk-beluknya. Maksudnya darimana dibeli makanan itu, dengan uang dari hasil usaha apa, dan seperti apa bahan-bahan makanan itu diresep. Inilah yang menurut analisa peneliti bahwa ketekunan dalam menjalankan ajaran yang demikian bernilai ibadah sekaligus sebagai bentuk karakter dalam diri murid-murid Syekh H. Mhd. Ihsan Harahap yang mampu mencapai tarafnya sebagai khalifah. Hal syubhat dianggap sebagai bentuk yang harus dihindari meskipun harus mengorbankan kepentingan diri sendiri karena hal ini juga menyangkut perasaan orang lain. Selain itu, hal ini juga bentuk dari pensucian diri dan pertanggungjawaban di akhirat kelak.

\section{KESIMPULAN}

Motivasi suluk 5 hari pada tarekat Naqsyabandiyah bimbingan Syekh H. Mhd. Ihsan Harahap dapat dilihat dari adanya Panggilan Jiwa Beribadah dalam murid yang mengikuti dan inovasi syekh untuk memudahkan proses berkhalwat dalam persulukan. Kemudian secara ekstrinsik adalah adanya sosialisasi syekh melalui dakwah keliling, pengaruh teman dan pola pikir masyarakat bahwa efisiensi waktu beribadah dengan suluk 5 hari.

Ketekunan beribadah murid usia minus 40 tahun setelah selesai suluk 5 hari tarekat Naqsyabandiyah bimbingan Syekh $\mathrm{H}$. Mhd. Ihsan Harahap adalah dapat dilihat dari keaktifan dalam beribadah dengan menjaga waktu shalat, peramalan ibadah nawafil, wirid dan zikir serta keaktifan dalam keberagamaan di masyarakat sebagai bentuk ketekunan dalam menjalankan ibadah mahdah dan ghaira mahdah. Pembuktian dan kata tentang hal tersebut diperoleh dari observasi dan wawancara dengan masyarakat lain dan juga murid, khalifah dan syekh $\mathrm{H}$. Mhd. Ihsan Harahap sendiri sebagai mursyid dan pimpinan persulukan. 


\section{DAFTAR PUSTAKA}

Abdul Shamad Al-Palimbani. Syaral-Salikin Juz I, Beirut: Maktabah Al-Mukarramah, tt.

Ahmad Rohani dan H. Abu Ahmadi, Pengelolaan Pengajaran, Jakarta: Rineka Cipta, 2000.

Bey Arifin dan Abdullah Said, Rahasia Ketahanan Mental dan Bina Mental dalam Islam, Surabaya: Al-Ikhlas, 1981.

Departemen Agama RI, Al-Qur'an dan Terjemahnya, Semarang: Toha Putra, 2009.

Dimyati dan Mujiono, Belajar dan Pembelajaran, Jakarta: Rineka Cipta, 1999.

Fuad Said, Hakekat Tarekat Naqsyabandiyah, Jakarta: Pustaka Al-Husna, 1994.

Imam Bukhari. Terjemahan Shahih Bukhari, Juz IV, Semarang: Dahlaq tt.

Imran Abu Ammar, Di Sekitar Tarekat Naqsyabandiyah, Kudus: Menara, 1950.

Lexy J. Moleong, Metode Penelitian Kualitatif Edisi Revisi, Jakarta: Rosda Karya, 2010.

Mahmud Yunus, Kamus Arab-Indonesia, Jakarta: Hidakarya Agung, 1989.

Muhammad Fuad Abdul Baqi, Al-Mu'jam Al-Mufarros li Al-Fazhi Al-Qur'an Al-Karim, Beirut: Dar Fikr, tth.

Najamuddin Amin Al-Kurdi, Tanwir Al-Qulub, Beirut: Dar Al-Fikr, tt

Norman K. Denzin dan Yvonna S. Lincoln (ed), Handbook of Qualitative Research, Terj. Dariyatno dkk., Yogyakarta: Pustaka Pelajar, 2009.

Oemar Hamalik, Kurikulum dan Pembelajaran, Jakarta: Bumi Aksara, 1995.

Studi Pendahuluan, Wawancara dengan Syekh H. Mhd. Ihsan Harahap, Mompang, 25 Mei 2014.

Sugiono. Metode Penelitian Kuantitatif, Kualitatif dan R \& D, Bandung: Alpabeta, 2008.

Syekh Ahmad al-Alawi, Wali Sufi Abad 20, terj, Abd Hadi Bandung: Mizan, 1989.

Tim Penyusun Pusat Bahasa, Kamus Bahasa Indonesia, Jakarta: Balai Pustaka, 2008.

Toeti Soekamto, dkk, Prinsip Belajar dan Pembelajaran, Jakarta: PPAI Dirjen Dikti-Depdikbud, 1993. 